\title{
An Empirical Analysis of Disinvestment Policy in India: Does Ideology matter?
}

\author{
Ritika Jain $^{1}$ and Shubhro Sarkar ${ }^{2}$ \\ Indira Gandhi Institute of Development Research
}

May 2015

\begin{abstract}
The paper analyzes the extent to which the ideology of parties within a coalition as well as the ideological differences between the parties ruling at the center and the states, influence the decision to privatize state owned enterprises. Using panel data estimation for limited dependent variable and sample selection models, we identify political, industry specific, firm specific and macroeconomic variables which influenced the decision to divest central public enterprises in India between 19912010. We find that higher partial privatization is driven by a more right-winged coalition, lower ideological spread in the coalition and lower ideological difference between the center and the state in which the public enterprise is located. We also find that after the government selects larger, more experienced and more profitable firms, it divests to a larger extent the relatively less experienced and less profitable firms.
\end{abstract}

JEL classification: P16, D22, L33, C33

Keywords: political economy, disinvestment, panel data, sample selection, ideology

\section{Introduction}

Among the studies which provide a political economy perspective of privatization of state owned enterprises (SOEs), there are several which show that the ideology of the ruling party plays a key role in the decision-making process. For example, Boubakri, Cosset, Guedhami, and Saffar (2011), Boehmer, Nash, and Netter (2005), Bortolotti and Siniscalco (2004) and Megginson, Nash, Netter, and Poulsen (2004) report findings from a panel data regression analysis, where they use an indicator variable to account for a right-leaning ruling party. While instructive in their own right, these studies provide an incomplete appraisal of the role of ideology in the

\footnotetext{
${ }^{1}$ Assistant Professor, Centre for Development Studies, Trivandrum. Email:ritika@cds.ac. in

${ }^{2}$ Associate Professor, Indira Gandhi Institute of Development Research, Mumbai. Email:shubhro@igidr.ac.in. We thank Dr. C Veeramani, Dr. Soumyanetra Munshi and Dr. Nityananda Sarkar for their comments and suggestions. We are also grateful to seminar participants at IGIDR, Mumbai and Asian Meeting of the Econometric Society, 2013 for valuable feedback. We extend our gratitude to seminar participants of DSE Winter School, 2013, 9th ACEGD Conference at ISI, Delhi, 2013, Jadavpur University Public Policy Conference, 2014, SIMS- School of Economics, January 2015, Centre for Development Studies, March 2015 and Indian Institute of Management, Ranchi, March 2015
} 
(partial) privatization process, as they consider the ideology of the majority party only.

With the extant literature in mind we ask, to what extent is a coalition, comprising parties having different ideologies, inclined to privatize the SOEs? Is the privatization process stymied only by the veto power (measured through seat shares) of parties belonging to a ruling coalition or those outside it? Or does ideological differences between parties in the ruling coalition or those between parties ruling at the center and the state in which an SOE is located, play a crucial role as well?

Moving away from the binary variable approach, we construct three ideologybased measures. Given the ideology score of each party, we define (i) the ideology score of a coalition as the weighted sum of ideology scores of parties in the coalition, with seat shares in the coalition as weights (ii) ideological spread of a coalition as the weighted variance of ideologies in the coalition and (iii) the ideological difference between the center and the state in which the SOE is located as the absolute difference of ideology score of the coalition at the center and that of the ruling party in the corresponding state.

We then hypothesize that (a) the probability of partial privatization should be higher for a right-leaning coalition than a left-leaning one (b) a lower ideological spread within a coalition should improve the possibility of partial privatization and (c) a lower ideological difference between the center and the state should improve the chances of privatization. Our first hypothesis attempts to answer the question as to how frequently a coalition containing several parties, each with a different ideology, will divest an SOE. Our second hypothesis is complementary to the result that political fragmentation plays a significant role in explaining the government's decision to privatize (Bortolotti and Pinotti (2008)). Given the contentious nature of a structural process such as divestment, we contend that a coalition comprising parties with different ideologies would either be unable to reach a consensus or would require a longer time to reach an agreement than an ideologically convergent coalition.

To understand the interplay of the ideological measures mentioned above, let us consider an example of a coalition of two parties, trying to decide whether or not to divest an SOE. Let us assume that the ideological stances of the parties are represented by the corresponding ideal privatization levels of the SOE (say $\theta_{1}, \theta_{2}$ with $\theta_{1}>\theta_{2}$ ). In this case, a convergence (divergence) of the bliss points effected by a reduction (an increase) in $\theta_{1}$, will not be sufficient to ensure a higher (lower) probability of privatization, since such a convergence (divergence) would simultaneously push the coalition to the left (right). It would therefore be interesting to carry out an empirical analysis of the impact of such ideological factors.

While the central government could be keen to infuse efficiency in the public sector and to raise funds to finance a fiscal deficit, it cannot discount the political 
fallouts of such a decision, which is deemed to raise the possibility of job cuts and widen income inequality. While the benefits from the privatization process accrue to the central government in the form of monetary proceeds, the costs are borne by the local population. The skewed nature of the policy incentivizes the state governments to oppose privatization in their own states. We conjecture that an incumbent state party having a different (similar) ideological stance on privatization than the one at the center would have a stronger (weaker) incentive to oppose such a move ${ }^{3}$. Related to this supposition is a study by Dinc and Gupta (2011), who provide evidence that delays in privatization are expected in regions where the national ruling party faces a close race with its opposition. However, our measure of center-state ideological difference is uncorrelated with the level of political competition that the ruling party faces from its opposition across various states, even when we assume that the opposition party is incumbent in states in which SOEs are located. For example, if voters are uniformly distributed over a compact policy space, then in a two-party election, parties will have equal vote shares when (a) the ideal privatization levels of both the parties are at the same point and (b) the bliss points are equidistant from the center. In such a setting, our hypothesis will be markedly different from that of Dinc and Gupta (2011) in case (a). To examine the role of ideology in privatization decisions we focus on the experience of India, in which partial privatization is officially refered to as "disinvestment". We construct a unique dataset by combining the data of the financial performance and disinvestment history of all central government owned non-financial firms from 1991-2010. We also include political, macroeconomic and industry specific factors in the regression analysis to analyze (1) first time selection of SOEs for disinvestment (2) occurrence (or repeated selection) of disinvestment over time and (3) extent of disinvestment. While estimating the model for extent of disinvestment, we use a two-step estimation procedure to account for sample selection bias (Heckman (1979)) . To calculate the ideology scores of political parties in India, we refer to the studies of Dash and Raja (2014) and Chhibber and Nooruddin (2004), in which major parties were coded based on their manifestos and policies that they had either prescribed or implemented in the past ${ }^{4}$. India provides an ideal background for our study as the inception of its disinvesment policy coincided with the commencement of an era of coalition led governments at the center. During the period of our study, there were six national level elections, of which three were won by the Indian National Congress (INC) and its allies and the remaining three were won by a coalition led by the relatively right-leaning Bharatiya Janata Party (BJP). The

\footnotetext{
${ }^{3}$ We claim that this result will hold even if the incumbent state party is more market oriented that the one at the center.

${ }^{4}$ For the remaining local parties, the scores were calculated on the basis of media reports. The ideology scores were integers ranging from 1 to 5 , with 5 denoting left-wing.
} 
coalitions formed by these parties varied in terms of the number, as well as the ideology of the allies. There was also sufficient heterogeneity in the ideology of the incumbent parties in the states in which the SOEs were located.

We find strong empirical support in favor of all our three hypotheses which posited the role of different ideology-based measures in the decision to privatize SOEs. Our results also suggest that the selection of firms along with the extent of disinvestment follows an interesting pattern. The government first selects more profitable, productive and bigger SOEs for disinvestment; from that same set, a larger proportion of ownership is transferred for the relatively smaller, less profitable and productive firms. This pattern is indicative that the government is pursuing the twin objectives of reducing budgetary deficit and improving performance of public sector enterprises. We also find that coalition governments with dissimilar ideological parties are more willing to divest the same public enterprise multiple times than to select new firms for disinvestment. A possible reason for such a pattern is that the costs which are associated with partial privatization of an SOE which has already been selected in the past are lower than those incurred from selecting a new enterprise.

\section{Ideological Influence}

While bridging the fiscal deficit and improving the performance of SOEs are oftencited drivers of the disinvestment process ${ }^{5}$, we argue that the adoption and implementation of such a policy will be influenced by the ideologies of the political parties which constitute a ruling coalition, as well as by the ideologies of (national and local) opposition parties.

Following the definition of political ideology, which is a "set of beliefs about the proper order of society and how it can be achieved" (Erikson and Tedin (2003)), and that ideologies "specify acceptable means of attaining social, economic, and political ideals" (Jost, Federico, and Napier (2009)), it is natural to expect that such an ideology is a multidimensional construct. However, our focus is on one of these dimensions, namely, whether SOEs should be divested for attaining micro and macro level objectives mentioned above. Eliciting the true ideological position of a party on this dimension can be challenging, as policy announcements and reactions

\footnotetext{
${ }^{5}$ Naib (2004) states “... the government had constituted a committee in Feb 1992, under V. Krishnamurthy, the then Member of Planning Commission, to institutionalize the disinvestment process. The terms of reference of the committee were to devise criteria for selection of PSEs for disinvestment in 1992-93. The committee indicated that two of the important objectives sought to be achieved through disinvestment were to bridge the fiscal deficit and improve performance of public sector enterprises."
} 
are often colored by the status of the party as that of an incumbent or one belonging to the opposition.

In India for example, two left parties, the CPI(M) and the CPI demanded scrapping of the disinvestment policy on May $14,2004^{6}$ and in a press release on November 6, 2009 a group of Left parties comprising the RSP, CPI, CPI(M) and the AIFB, strongly condemned the decision of the Union Cabinet to disinvest shares in all profitable PSEs ${ }^{7}$. On the contrary, in 2001 the BJP defended the center's decision to sell off $51 \%$ equity in $\mathrm{BALCO}^{8}$, when it was the leading party in the ruling coalition. A year later, in a press release in 2002, BJP spokes person Arun Jaitley highlighted the success of the disinvestment transactions carried out during the BJP regime ${ }^{9}$. According to AK Bhattacharya, editor of the Business Standard, disinvestment of government equity in PSUs had become a low-priority item on the government's agenda, as long as the Left parties were part of the UPA between 2004 and 2009. The total proceeds from disinvestment during those five years amounted to only about Rs 6,700 crore, compared to over Rs 33,650 crore during the preceding six years of the BJP's tenure ${ }^{10}$.

These excerpts suggest that political ideology plays a critical role in the decision to privatize SOEs and given that coalition governments are in place in many countries across the world, one needs to examine this role within a framework which elicits the intra-coalition and inter-government (center-state) dynamics.

\section{Review of Literature}

Since our paper aims to contribute to the literature on political economy of privatization, we review selected studies which provide evidence as to whether political factors affected disinvestment decisions of governments comprising a single party or a coalition. Megginson and Netter (2001) offers a broader review of empirical studies on privatization.

Biglaiser and Brown (2003) uses a panel data set encompassing 16 LatinAmerican countries between 1980-1997 and examines whether firm-level conditions, macroeconomic conditions, democracy regimes and political factors affect

\footnotetext{
${ }^{6}$ http://articles.economictimes . indiatimes . com/2004-05-14/news/27413798_1_ disinvestment-policy-psus-left-parties

${ }^{7}$ http://cpim.org/content/left-parties-cancel-disinvestment

${ }^{8}$ http://hindu.com/2001/02/25/stories/02250005.htm

${ }^{9}$ http://articles.timesofindia.indiatimes.com/2002-09-02/india/27312887_1_ disinvestment-oil-sector-psus

${ }^{10} \mathrm{http}$ ://www . business-standard.com/india/news/a-k-bhattacharya-disinvestment-withoutpurpose/ 373828/
} 
the amount of privatization of SOEs. Their results suggest that political and intercountry differences play a significant role in the privatization decision. Bortolotti, Fantini, and Siniscalco (2004) investigate privatization in 34 countries for the period 1977-1999, where they employ probit and panel data methods and identify hard budget constraints, a right-wing incumbent government, legal origin and stock market liquidity to be important factors for a privatization program. Similar findings are reported by Bortolotti and Siniscalco (2004), who analyze the causes of disinvestment in both developing and developed economies and conclude that high per capita income, developed financial markets, high levels of debt and a right-wing government in office spur privatization.

Boehmer et al. (2005) analyze a panel data set of 101 countries from 19822000 to examine the relevance of economic, political and institutional factors in privatizing state owned banks and suggest that political factors are important in privatization decisions in developing nations but not in developed ones. However, economic factors influence privatization decisions both in developing and developed nations. Similarly, Bortolotti and Pinotti (2008) presents a dataset for 21 industrialized countries from 1977-2002 and tests the effect of political institutions and partisan orientation on privatization policy. Using hazard rate models they show that greater political fragmentation, measured by the number of parties with veto power, leads to delays in privatization and reduces executive stability.

There has also been some research on the impact of ideologies of parties constituting a coalition on economic liberalization in various countries. For example, Potrafke (2010) investigates the extent to which the ideology of a coalition influences deregulation of product markets in 21 OECD countries over the period 1980-2003. He uses two indices to measure government ideology, when the government comprises two or more parties having "different ideological roots". The first measure is discrete, in which the index takes value 1 if the share of right-wing parties in the government is larger than $2 / 3$, and 2 if it is between $1 / 3$ and $2 / 3$. The index increases to 3 if $50 \%$ of the seats are occupied by centrist parties or if left-wing or right-wing parties form a coalition government that it not dominated by either side. Finally, the index takes values 4 or 5 depending on the extent of domination of left-wing parties. For the second index, parties are placed on a fivepoint scale $(-1 ;-.5,0 ; .5,1)$ from left to right and the scores are weighed with the relative share of seats in the ruling coalition. This index (or a variant of it) is used in Bjornskov (2005) and Bjornskov (2008) and is similar to the index that we have constructed to measure ideological score of a coalition. Bjornskov and Potrafke (2011) use the first measure to show that right-wing coalitions in Central and Eastern Europe were more active in privatizing small and medium scale public sector enterprises than the left-leaning ones.

The next set of studies comprise firm level analyses, that complement the 
existing evidence on the political underpinnings of privatization. Boubakri et al. (2011) use a multivariate tobit analysis to study the effect of political, legal, firm specific and macroeconomic factors on the residual state ownership in 221 state owned firms in 27 emerging economies over the 1980-2001 period. Their results show that the political system, political cohesion, and government stability are significant determinants of residual state ownership in newly privatized firms, even after controlling for the influence of legal environment. Mizutani and Uranishi (2010) investigates the determinants of privatization of 74 special public Japanese corporations in 2001. Using cross-sectional probit analysis their study shows that public corporations which are in commercialized industries and are regulated by a single regulator are more likely to be privatized. Using firm level data from India for the period 1990-2004, Dinc and Gupta (2011) find that significant delay in privatization occurs if the main operational branch of a firm is in an electoral district where the ruling party faces a strong and well established opposition. However, this study (and others) does not use ideology-based measures like we do. More specifically, the degree of political competition considered in Dinc and Gupta (2011) has no one-to-one correspondence with the difference in ideology scores between the governments at the center and the state in which the SOE is located.

The central contribution of our paper is to offer empirical evidence as to how a coalition government, comprising parties having different ideologies, decides on (i) whether or not to privatize its SOEs, and in the event it resolves to do so, (ii) the extent of privatization. We believe that this question can be answered not by a cross-country study but by analyzing the data of a country which has had several incumbent coalitions. This is because the majority party has to convince not only the opposition parties located at the center and the state in which the SOE is located, but also its coalition allies, who could be ideologically averse to such a policy. A cross-country analysis which denotes the ideology of a government or a coalition by a discrete or a continuous measure is able to explain the marginal effects of such regressors on the probability of privatization but fails to account for the players who have veto power, both within the government (coalition), and those outside it. In the absence of a theoretical model, our study is the first which constructs three ideology-based measures, which helps us explain the intra-coalition and center-state dynamics of the decision making process and shows how they affect the incidence of privatization. Apart from being the first study which uses these ideology based measures on a cross sectional time series data of a country, our paper is also the first to use such measures to represent the notions of political fragmentation within a party and the political competition that the ruling party faces in the state in which an SOE is about to be privatized. While Bortolotti and Pinotti (2008) use seat shares to represent political fragmentation, Dinc and Gupta (2011) use vote shares of the incumbent and opposition parties to measure political competition. Finally, 
our paper is the first to show that the disinvestment of SOEs in India has followed a particular pattern: it selects larger, more profitable firms for disinvestment and from within that set privatizes to a larger extent the less profitable ones.

\section{Hypotheses Formulation}

To outline the extent to which ideology of parties belonging to the ruling coalition or the opposition influence the process of privatization, we present the following hypotheses, which are based on three ideology-based measures.

\subsection{Ideology Orientation}

It is well established in the empirical literature that the presence of a right-wing government significantly improves the chances of partial privatization of public sector enterprises (Megginson et al. (2004), Clarke and Cull (2002), Boubakri et al. (2011), and Bortolotti et al. (2004)), state owned banks (Boehmer et al. (2005)) and overall reforms Biglaiser and Brown (2003)). This observation resonates with the belief that conservative and neo-liberal parties represented by market oriented politicians advocate policies such as deregulation, privatization and fiscal austerity.

Theoretical support for the hypothesis that right-wing parties favor such policies is found in Perotti (1995) and Biais and Perotti (2002). In a setting where a government is unable to precommit towards a policy for an SOE, Perotti (1995) shows that underpricing and partial privatization could work as a commitment mechanism, as it signals a willingness to bear residual risk to private investors. Biais and Perotti (2002) on the other hand emphasize on the strategic use of partial privatization by neo-liberal parties, who allocate large amounts of shares of public enterprises to the median-class voters, with the aim of shifting their preferences away from the left.

While these findings are relevant for single-party governments, it is not evident how a coalition government, comprising parties of different ideologies, decides whether or not to privatize SOEs. This is an important question which remains largely unaddressed in the literature, given the prevalence of coalition governments in Europe and in Asia. To analyze the extent to which the ideology of a coalition government affects the incidence of privatization, we construct an ideology score of a coalition by using a weighted sum of the ideology scores of parties comprising it. The weights used in this measure are given by the corresponding seat shares in the coalition, and are indicative of the bargaining powers of its members. Given the preponderance of evidence that privatization efforts are galvanized by the presence 
of right-wing ruling parties, we believe that a similar result will hold whenever the coalition as a whole has a neo-liberal agenda.

Hypothesis I : Ceteris paribus, coalition governments leaning towards the right should be more likely to divest than their left-leaning counterparts.

\subsection{Ideology Difference}

Dinc and Gupta (2011) argue that disinvestment as a phenomenon is unbalanced in the way its benefits and costs are distributed; while the benefits from the proceeds of sales are available to the entire population, the costs are borne by the locals. This implies that regions where these firms operate, disproportionately bear the costs of privatization, which in turn makes the respective state governments averse to such a policy. We contend that the magnitude of the opposition from the state government is directly related to the ideological difference between the central and state governments, and that the implementation of such a policy is more difficult if the state government (where the selected firm is located) is further away from the center in the ideological spectrum ${ }^{11}$.

Evidence from reality reiterates the fact that state governments oppose disinvestment decisions of SOEs if the main headquarters are located in their states ${ }^{12}$. Based on these observations, we formulate the next hypothesis:

\footnotetext{
${ }^{11}$ Empirically this is comparable to the "political competition" measure used by Dinc and Gupta (2011) but both the measures are very different in two important aspect- rationale behind using the measures and what each tries to capture. The rationale behind Dinc and Gupta (2011) "political competition" is that it is politically costly for the Centre to select firms from districts where it faces a strong opposition. In contrast, the rationale behind ideological difference in the present study is that it is costly for the Centre to select a firm which is located in state run by an ideologically dissimilar government. In other words, it is easier for the Centre to select firms for a politically sensitive policy from ideologically similar states. Secondly, the measure used for political competition is based on the number of seats won by the winning party in the Lok Sabha elections. On the other hand, ideological difference is captured as the ideological distance between the Centre and the state government.

${ }^{12}$ In 2012 when United Progressive Alliance (led by Indian National Congress) was in power in the Centre, Biju Janata Dal (BJD), a Centre-right party, opposed the disinvestment decision of NALCO. The BJD was in power in Odisha during that time and NALCO had its headquarters in Bhubaneshwar, the capital of Odisha. Similar instances happened in the past when Hindustan Aeronautics Limited was selected for disinvestment in 2011 and with AIADMK and DMK opposing disinvestment of PSEs in Tamil Nadu back in 2004. Source: http://www . thehindubusinessline.com/news/states/article3915070. ece,http://ganashakti. com/news-storage/news-details/article/stop-disinvestment-of-hal-bhel.html, http://articles.timesofindia.indiatimes.com/2002-12-04/india/27302899_1_ disinvestment-privatisation-arun-shourie
} 
Hypothesis II: Ceteris paribus, low ideological difference between the center and the state government should increase the incidence of disinvestment.

\subsection{Ideology Spread}

The formation of coalitions is driven by factors broader than the narrow paradigm of ideological similarities between parties. Other strategic factors may also play a significant role in the birth of a coalition. This may lead to a situation where two ideologically divergent parties are a part of the same coalition and have to take a decision on a contentious issue such as disinvestment. To incorporate this feature of ideological differences within a coalition we take the weighted variance of ideological scores of parties within a coalition and define it as the ideology spread of a coalition. While this measure may be construed to be a proxy of political fragmentation, it is significantly different from other measures used in the literature. For example, Bortolotti and Pinotti (2008) define political fragmentation by the effective number of parties

$$
E N P=\left[\sum_{j \in P}\left(\frac{s_{j}}{\sum_{k \in P} s_{k}}\right)^{2}\right]^{-1},
$$

where $s_{j}$ is the number of seats occupied by party $j$ and $P$ is some coalition of parties. We contend that this measure of political fragmentation is misleading when all the parties in the coalition have the same ideology. Based on our measure we formulate the following hypothesis:

Hypothesis III: Ceteris paribus, low ideological spread within a coalition at the center should improve the chances of disinvestment.

An examination of disinvestment objectives unfolds conflicting sides to the policy. To bridge the fiscal deficit/debt gap using disinvestment as a program would require more firms and probably the better performing ones being selected ${ }^{13}$. However, the objective of infusing efficiency and productivity of public sector enterprises would make the worst performing public sector enterprises the best candidate for being selected. This would lead to high magnitudes of efficiency gains, which the policy aims at and would also make the sick SOEs at par with other well

\footnotetext{
${ }^{13}$ This is based on the rationale that better performing public sector enterprises are more valued and hence fetch better proceeds from their sale. To be more specific, the government may select a better -valued firms and divest it by $10 \%$ to get more money rather than select 10 worse performing firms and divest low portions of it to get lower proceeds. The first situation may be less resisted by the public in general than the former one. Example: http://www.hindustantimes.com/business-news/Markets/ Coal-India-disinvestment-on-course-despite-woes/Article1-1063172.aspx
} 
performing private sector enterprises. These two objectives suggest that the relation between firm specific factors and disinvestment decision cannot be predicted apriori. Since we do not have strong evidence to formulate a set of hypotheses for the relation between firm performance and disinvestment decision, we resort to an empirical investigation.

\section{Data}

We construct a unique dataset by compiling the information on all the manufacturing and non- financial services CPSEs (approximately 240 for each year) for 21 years (1991-92 to 2010-11). We have not considered the three strategic cognate groups (Arms and ammunition and the allied items of defense equipment, defense aircrafts and warships; atomic energy and railway transport) in our dataset which the Department of Disinvestment had excluded from disinvestment in 1999. The details of the data set are presented in Table 3.1

\section{Construction of Variables}

To test the hypotheses formulated in Section 4 we construct some unique yet simple measures of ideology. The dominance of coalition makes the role of ideology crucial in the design and implementation of politically driven policies like disinvestment in any empirical investigation. In this situation, using a dummy variable to capture ideology would be rather naive. To the best of our knowledge, this study is the first of its kind to take a multi- dimensional approach to capture the role of ideology in decision making and implementation of disinvestment. We have used three simple measures to test the three hypotheses described in the previous section.

\subsection{Ideology Score}

With the wide era of coalition politics constructing an index of ideology for coalition governments is a challenging task. To compute the ideology index, we use the weighted average of the ideology of all parties in the winning alliance where weights are the Lok Sabha seat share won by each of them. This is the ideology of the coalition. However, a more complex and fundamental problem lies in assigning an ideology score for each of the parties forming a coalition. As a solution, we refer to ideology scores based on Chhibber and Nooruddin (2004) and Dash and Raja (2014). This study has coded major national and regional political parties in India based on their party objectives and policies that these parties have prescribed 
The table presents a brief profile of the dataset based on the categories of variables used in the analysis.

\begin{tabular}{|c|c|c|c|}
\hline $\begin{array}{l}\text { Categories of } \\
\text { variables }\end{array}$ & Broad source & Brief information on variables & Comments \\
\hline Disinvestment & $\begin{array}{lr}\begin{array}{l}\text { Public } \\
\text { Survey, }\end{array} & \text { Enterprise } \\
\text { of } & \text { Department } \\
\text { www.bsepsu.com }\end{array}$ & $\begin{array}{l}\text { Selection of disinvestment and } \\
\text { percentage divested }\end{array}$ & Hand collected \\
\hline $\begin{array}{l}\text { Firm specific } \\
\text { variables }\end{array}$ & Public Enterprise Survey & $\begin{array}{l}\text { Firm size, age, profitability, pro- } \\
\text { ductivity, ratna status, firm loca- } \\
\text { tion }\end{array}$ & Hand collected \\
\hline $\begin{array}{l}\text { Macroeconomic } \\
\text { Variables }\end{array}$ & $\begin{array}{l}\text { Reserve Bank of India, } \\
\text { MOSPI }\end{array}$ & $\begin{array}{l}\text { Per capita income, fiscal deficit, } \\
\text { fiscal debt, stock market return }\end{array}$ & \\
\hline $\begin{array}{l}\text { Political Vari- } \\
\text { ables }\end{array}$ & $\begin{array}{l}\text { Election Commission of } \\
\text { India, Press Notes and } \\
\text { other published studies }\end{array}$ & $\begin{array}{l}\text { Ideology score, ideology differ- } \\
\text { ence, ideology spread, political } \\
\text { fragmentation, exante stability, } \\
\text { expost stability }\end{array}$ & $\begin{array}{l}\text { All variables con- } \\
\text { structed }\end{array}$ \\
\hline $\begin{array}{l}\text { Industry vari- } \\
\text { ables }\end{array}$ & $\begin{array}{l}\text { Public Enterprise Sur- } \\
\text { vey, Annual survey of } \\
\text { industries, policy docu- } \\
\text { ments }\end{array}$ & $\begin{array}{l}\text { Industry type, Deregulation per- } \\
\text { centage }\end{array}$ & $\begin{array}{l}\text { Deregulation extent } \\
\text { in an industry is cal- } \\
\text { culated at NIC } 2 \text { digit } \\
\text { level }\end{array}$ \\
\hline $\begin{array}{l}\text { Changes in } \\
\text { policies }\end{array}$ & $\begin{array}{l}\text { Government policy doc- } \\
\text { uments }\end{array}$ & Scope for disinvestment & Hand constructed \\
\hline
\end{tabular}

Table 1: Description of data and data sources 
to and implemented in the past. The study covers all the major parties. For the few remaining ones, the information has been collected from media reports. The ideological strand, as described, spreads from 1 to 5 where right is coded 1, right centre 2, centre 3, left centre 4 and left 5. ${ }^{14}$ The data on coalition members for different Lok Sabha is taken from Sridharan (2010). It may be formulated as

$$
\operatorname{Index}_{j}=\sum_{i=1}^{n} I_{i j} w_{i j}
$$

where $i$ and $j$ denote the party and year respectively. $I_{i j}, w_{i j}$ and Index $j$ is the ideology of the $i$ th party, seat share of the $i$ th party in a $N$ party coalition and ideological score of the coalition in the $j$ th year. The index ranges from 1 to 5 . It is a continuous variable and is lower, the more a coalition government is oriented towards the right wing of ideological spectrum.

\subsection{Ideology Difference}

Ideology difference is captured as the difference in ideology between the Centre and the state where the CPSE is located. As a first step to construct this measure, we identify the state where the headquarters of each of the public sector enterprise is located. Then we code the ideological orientation of each party ruling the state based on the ideological scores. Finally, we take the squared difference between the ideologies of the Centre and the state. We do this for all the CPSEs during our period of analysis. It is represented as follows:

$$
\text { Stateindex }{ }_{j}^{s}=\left(I_{j}^{s}-\text { Index }_{j}\right)^{2}
$$

where $\operatorname{Index}_{j}, I_{j}^{S}$ is the ideology of the coalition at the Centre and ideology of the main party in state $s$ in the $j$ th year respectively. Stateindex ${ }_{j}^{s}$ is the ideological difference between the sth state and centre in the $j$ th year. It ranges from 0 to 5 and is a continuous variable ${ }^{15}$. A value 0 indicates that the two governments have exactly the same ideological orientation. On the other hand, a value 5 indicates that the two governments' ideologies are diametrically opposite to each other.

\footnotetext{
${ }^{14}$ We assume that the ideology orientation of a party does not change overtime.

${ }^{15}$ Since the data on coalitions is not available at the state level we take the ideology of the ruling party (assuming it is a single party) at the state level.
} 


\subsection{Ideological Spread}

Ideological spread is the ideological dispersion existing in a coalition in the Centre. It is captured as the weighted variance of ideologies in a coalition in the Centre. The weights used are the seat share of each party in the coalition. The measure is a useful measure to capture intra coalition ideological spread. It is measured as follows:

$$
\text { Spread }_{j}=\frac{N^{\prime \prime}}{N^{\prime \prime}-1} \sum_{i=1}^{n}\left(I_{i j}-\text { Index }_{j}\right)^{2}
$$

where $I_{i j}, w_{i j}$ and Index $j$ is the ideology of the $i$ th party, seat share of the $i$ th party in a $N$ party coalition and ideological score of the coalition in the $j$ th year. Spread $_{j}$ is the ideological variance of the coalition in the $j$ th year and $N^{\prime \prime}$ is the number of non-zero weights. It is a non-negative number. And a high ideological spread indicates that after accounting for all seat shares of each party in the coalition, there is high intra- coalition ideological variance which is undesirable for disinvestment decisions.

The construction of other political, firm specific variables and other important control variables has been discussed in details in Appendix A.

\section{Descriptive Statistics}

In this section, we compile some trends and patterns followed by disinvestment proceeds overtime, number of firms selected for disinvestment and similar variables. We also use simple correlation coefficients to investigate the relevance of the use of constructed variables in explaining the disinvestment decisions. The summary statistics of all the variables is enclosed in Appendix B. Figure 1(a) shows the trend of real disinvestment proceeds in contrast with the target overtime. Actual proceeds is the total proceeds collected from disinvestment transactions in a particular year deflated by IIP (base year- 2004-05). Figure 1(b) plots the number of firms selected for disinvestment in a particular year ${ }^{16}$.

\footnotetext{
${ }^{16}$ It is observed that there was no disinvestment in the years 1993-94, 2006-07 and 2008-09. In 1993-94, disinvestment was not adopted despite a target amount of Rs 3,500 crore because of unfavorable market conditions, no clear-cut policy on disinvestment among others. The steep rise in proceeds (as opposed to the low number of firms selected) between 1999-2000 and 2003-04 indicates the disinvestment proceeds collected from the strategic sale of CPSEs where the government sold atleast $51 \%$ of ownership of each of the firms selected. However, in 2005-06, government declared disinvestment to be a useful tool that should be selectively employed. It announced the need for establishment of Board of Reconstruction of Public Enterprise (BRPSE) which would advise on the measures to be taken by the government for the restructuring of PSEs.
} 
The table presents the correlation coefficient between disinvestment variables and other important variables

\begin{tabular}{lrr}
\hline Variable & Actual Disinvestment Proceeds & Number of firms disinvested \\
\hline Real per capita Income & -0.23 & 0.53 \\
Fiscal deficit & 0.7 & -0.77 \\
Total Debt & 0.25 & 0.7 \\
Stock Return & 0.04 & 0.39 \\
Stability & 0.1 & 0.34 \\
Political fragmentation & -0.19 & -0.55 \\
Ideology & -0.55 & -0.47 \\
Crisis Distance & -0.19 & -0.57 \\
\hline Source: Computed from the dataset & &
\end{tabular}

Table 2: Correlation coefficients of disinvestment variables with other variables

As is evident, in more than $75 \%$ of the analysis period, targeted proceeds exceed the real proceeds. This shows that the government fails to meet its targeted disinvestment programme because of some factors hindering the implementation of the policy as planned. In other words, targeted proceeds are driven by the objectives laid down for disinvestment policy. However, real proceeds may be strongly influenced by political factors as well. Also, mere $5 \%$ of total firms are selected for disinvestment every year on an average, since inception. However, these 5\% firms make $30 \%$ of total assets each year on an average. The average assets of divested firms is five times fully government owned public enterprises. This reflects that larger firms are more important for disinvestment as compared to smaller firms. In this panel of figures we try to superimpose the trend followed by disinvestment on the various political regimes. As a next step, in Table 2 we compile the correlation coefficient of the disinvestment variables with the rest of the variables.

The correlation coefficients between per capita fiscal deficit with both real disinvestment proceeds and the number of firms disinvested is as high as 0.8. Also, the correlation coefficients between ideology is approximately -0.5 with both the

The establishment of BRPSE and its policy objectives lead to a stagnation in disinvestment for a year (2006-07). The trend followed in 2008-09 to 2011-12 is related to the global crisis. In view of the difficult economic situation due to the global slowdown the government decided to give one time exception for utilization of proceeds from disinvestment for a period of three years (200912). Thus we see a dip and then rise in the disinvestment proceeds in the post 2008 period. The disinvestment proceeds during this period is available in full for investment in specific social sector schemes decided by the Planning Commission/ Department of Expenditure. 
The table presents the various Lok Sabha term in India and the disinvestment profile in each term

\begin{tabular}{lllllll}
\hline $\begin{array}{l}\text { Lok } \\
\text { Sabha }\end{array}$ & $\begin{array}{l}\# \text { ruling } \\
\text { parties }\end{array}$ & $\begin{array}{l}\text { Major } \\
\text { party }\end{array}$ & $\begin{array}{l}\text { Coalition } \\
\text { ideology }\end{array}$ & $\begin{array}{l}\text { Seatshare } \\
\text { of the main } \\
\text { party }\end{array}$ & $\begin{array}{l}\# \text { firms } \\
\text { divested }\end{array}$ & $\begin{array}{l}\text { Average disin- } \\
\text { vestment } \%\end{array}$ \\
\hline & & & & & & \\
1991 & 3 & INC & 3 & $83.3 \%$ & 38 & $8 \%$ \\
1996 & 14 & BJP & 2.17 & $57.7 \%$ & 0 & $3 \%$ \\
1998 & 23 & BJP & 1.49 & $64.1 \%$ & 10 & $43 \%$ \\
1999 & 16 & BJP & 1.41 & $60.1 \%$ & 27 & $35 \%$ \\
2004 & 17 & INC & 2.69 & $65.3 \%$ & 6 & $12 \%$ \\
2009 & 11 & INC & 3.07 & $78.3 \%$ & 14 & $14 \%$ \\
\hline
\end{tabular}

* \%change in ideology between the main party and the coalition Source: Computed from the dataset

Table 3: Disinvestment against the Indian political timeline

variables. Another important factor in this analysis is the number of years since the 1991 crisis that India experienced. It is captured as the crisis distance in Table 2. The fact that the correlation coefficient between the crisis distance and the number of firms is high but between the crisis distance and disinvestment proceeds is low is a crucial point for our analysis. This suggests that since 1991 crisis, the probability of selection of firms for disinvestment is very low overtime. However the extent of disinvestment (which generates disinvestment proceeds) is not related to how far we have come in time since the crisis. One possible reason may be because proceeds are directly related to the deficit situation where as the number of firms is probably influenced by number of years since reforms.

Finally, it may be imperative to examine the political scenario prevailing in India at the Centre. Table 3 compiles a profile of several characteristics of the political condition. It suggests that disinvestment is diversified across different terms. The average disinvestment is high for BJP led Lok Sabha regimes.

\section{Econometric Methodology}

To capture the factors affecting disinvestment decision more accurately we consider sophisticated econometric tools. We use three separate regression frameworks by using three dependent variables which capture different dimensions of disinvestment- selection, occurrence and extent of disinvestment. Selection of firms 
for disinvestment would help in exploring how the government chooses firms for disinvestment for the first time where as occurrence of disinvestment captures the factors affecting firms being disinvested in a particular year. Although the latter question seems to be closely related to the former one, the two are essentially dissimilar in nature. The first question targets the types of firm being selected for disinvestment where as the second one focuses on the disinvestment pattern in a particular year. The two questions may help us in exploring patterns about disinvestment decisions made by the governments. More specifically, it is a dual analysis that explains if the government selects the same firm for disinvestment repeatedly or continues to pick up new firms for disinvestment. As a final part of the question, we explore the factors affecting the extent of disinvestment (percentage disinvested) overtime.

The first two analyses (selection and occurrence)use a similar econometric methodology. A dichotomous dependent variable is regressed on a set of exogenous factors to get the estimated probabilities of disinvestment. This dichotomous variable takes the value 0 and 1 according to the disinvestment decision. For first time selection, we focus on whether a firm is being selected for disinvestment for the first time or not. A firm takes the value 1 as soon as it is selected for disinvestment for the first time. Also, to avoid capturing the effect of disinvestment in the following years, the firm is removed from the sample as soon as it takes the value 1 . For occurrence, the prime focus is to find the determining factors of disinvestment occurrence. So, here the dependent variable takes the value 1 whenever a firm is selected for disinvestment. We also treat first time and repeated disinvestment to be of equal importance and assign the same value 1 to both cases. In both the frameworks the dataset is an unbalanced panel to avoid attrition bias. Also, the economic factors are taken at lagged values where as the stock market and political variables are used as the current period value. We employ random effects with probit model for our estimation ${ }^{17}$.

For analyzing the extent of disinvestment we argue that this decision best represented as a two-stage process. There is the initial decision facing governments whether to disinvest or not, followed by a subsequent decision concerning the extent and size of these disinvestment transactions. Estimating two equations, one for the determinants of disinvestment and another for determinants of extent of disinvestment, independently may lead to inconsistent estimates in the second step because the second step considers a sample that is not randomly selected. In this respect, we employ a Heckman selection model, which helps in delivering consistent estimates 18 .

\footnotetext{
${ }^{17}$ The justification of using probit with random effects has been discussed in Appendix C

${ }^{18}$ The sample selection procedure is discussed in Appendix D
} 


\section{Results}

\subsection{First time Disinvestment}

We run random effects probit model to examine the factors influencing the selection of firms for disinvestment. To capture the selection of firms, we restrict our analysis to the first time selection of firms. Also, to avoid contamination of data and effect of repeated disinvestment we remove future observations of a firm as soon as it is divested in a particular year. Selection of firms is not a random selection. It is observed that mere $5 \%$ of total firms are selected for disinvestment every year on an average, since inception. However, these 5\% firms make $30 \%$ of total assets each year on an average. Also, the average assets of divested firms is five times the average assets of fully government owned public enterprises. This reflects that larger firms are more important for disinvestment as compared to smaller firms. So, if we use standard regression methodology by using unweighted regression we treat larger and smaller firms as being equally important for selection. However, because we have a non representative selection procedure it is more appropriate to use a weighted regression framework. This weight has been calculated as the average of the logarithmic transformation of asset size of each firm. The results from this are compiled in Table 4.

The estimation results suggest that selection of a firm for disinvestment for the first time is driven by a mix of political, macroeconomic and firm specific factors. More precisely, ideology, as captured by the three measures, plays an important role in selection. The three measures of ideology are significant at $1 \%$. The estimation results suggest that the more right winged a coalition government is, the higher is the probability of firms to be selected for disinvestment. Also, if ideology difference between the Lok Sabha and the state government of the firm (where it is located) is high the probability of selection of firms is low. Also, if the ideology dispersion in a coalition government is very high it is difficult to select firms for disinvestment. The results also show that favorable stock market conditions coupled with past few years' high fiscal deficit have a positive impact on the probability of selection of firms for disinvestment. Finally, probability of selection of firms is higher if the firm is more experienced, is more profitable, productive and is larger in size. This model specification takes a range of controls into considerationchange deregulation in industries, ratna status of firms, geographical location of firms, overall macroeconomic conditions and political conditions in the economy. We have also included industry dummies to control for the unobserved effects.

To test the robustness of our results we do a specificity and sensitivity analysis. On an average, the specificity and sensitivity for the above models are around $67 \%$ and $97 \%$ respectively. To verify the robustness of our variables we try ran- 
The table presents marginal effects for factors affecting first time disinvestment of central public sector enterprises.

\begin{tabular}{|c|c|c|c|}
\hline Selection of firms & Model I & Model II & Model III \\
\hline Ideology score & $\begin{array}{l}-0.764 * * \\
(0.344)\end{array}$ & $\begin{array}{l}-0.737 * * \\
(0.346)\end{array}$ & $\begin{array}{l}-0.849 * * * \\
(0.337)\end{array}$ \\
\hline Ideology difference & $\begin{array}{l}-0.084 * * * \\
(0.015)\end{array}$ & $\begin{array}{l}-0.085^{* * * *} \\
(0.016)\end{array}$ & $\begin{array}{l}-0.084 * * * \\
(0.016)\end{array}$ \\
\hline Ideology spread & $\begin{array}{l}-2.643 * * * \\
(0.717)\end{array}$ & $\begin{array}{l}-2.608 * * * \\
(0.720)\end{array}$ & $\begin{array}{l}-2.679 * * * \\
(0.695)\end{array}$ \\
\hline Stock Return & $\begin{array}{l}0.173 * * * \\
(0.035)\end{array}$ & $\begin{array}{l}0.174 * * * \\
(0.035)\end{array}$ & $\begin{array}{l}0.183 * * * \\
(0.035)\end{array}$ \\
\hline Fiscal deficit & $\begin{array}{l}1.842 * * * \\
(0.59)\end{array}$ & $\begin{array}{l}1.872 * * * \\
(0.591)\end{array}$ & $\begin{array}{l}1.638 * * * \\
(0.593)\end{array}$ \\
\hline Firm age & $\begin{array}{l}0.012 * * * \\
(0.001)\end{array}$ & $\begin{array}{l}0.012 * * * \\
(0.001)\end{array}$ & $\begin{array}{l}0.013 * * * \\
(0.001)\end{array}$ \\
\hline Firm size & $\begin{array}{l}0.127 * * * \\
(0.011)\end{array}$ & $\begin{array}{l}0.124 * * * \\
(0.011)\end{array}$ & $\begin{array}{l}7.72 * * * \\
(1.799)\end{array}$ \\
\hline Firm profit & $\begin{array}{l}0.098 * * * \\
(0.013)\end{array}$ & $\begin{array}{l}0.094 * * * \\
(0.014)\end{array}$ & $\begin{array}{l}2.619 * * * \\
(0.160)\end{array}$ \\
\hline Labor productivity & $\begin{array}{l}0.001 * * * \\
(0.000)\end{array}$ & $\begin{array}{l}0.000 * * * \\
(0.000)\end{array}$ & $\begin{array}{l}0.001 * * * \\
(0.000)\end{array}$ \\
\hline Firm efficiency & - & $\begin{array}{l}0.038 * * * \\
(0.007)\end{array}$ & - \\
\hline Delicensing & $\begin{array}{l}0.081 \\
(0.067)\end{array}$ & $\begin{array}{l}0.085 \\
(0.067)\end{array}$ & $\begin{array}{l}0.172 * * * \\
(0.069)\end{array}$ \\
\hline Geographical factors & Yes & Yes & Yes \\
\hline Industry Dummies & Yes & Yes & Yes \\
\hline Ratna Status & Yes & Yes & Yes \\
\hline Squared firm Variables & No & No & Yes \\
\hline No. of obs & 4145 & 4145 & 4145 \\
\hline Pseudo R squared & $37.20 \%$ & $37.40 \%$ & $39.81 \%$ \\
\hline
\end{tabular}

Note: The table presents marginal effects obtained from the random effects regression analysis for determinants of the selection of firms for disinvestment. Standard errors are reported within parentheses. $* * *$ and $* * *$ indicate significance at $10 \%, 5 \%$ and $1 \%$ respectively. Only choice variables are reported in the table. Model I and III does not include firm efficiency. Model II includes firm efficiency. Model III includes squared terms of firm specific variables. 
dom effects with probit model but without weights. Also, we run pooled probit model with clustered standard errors. We have tried the pooled probit models with and without importance weights and the results are consistent across various model specifications. Most of the variables behave as postulated in the hypotheses identified and as obtained in the main econometric specification. Also, to check the consistency of the results we reduce our sample size by removing the first year of disinvestment. This is because, a huge share of disinvestment transactions happened in 1991-92 under the pressure of external agencies like IMF. So we repeat the analysis by removing 1991-92 and most of the variables behave as expected.

\subsection{Occurrence of Disinvestment}

In the second part of this study we try to examine the factors influencing occurrence of disinvestment in a particular year. The main motivation behind this is the selection of some firms multiple times for disinvestment. To study occurrence behavior we assume that first time disinvestment is of equal importance as successive disinvestment. Instead of dropping firms that have been divested once, we retain the entire sample and give a value 1 if a particular firm is selected for disinvestment and 0 otherwise. Further, we add a variable 'disinvestment scope'. This is a variable that captures whether there is scope for disinvestment in public sector enterprises or not. It is calculated as the difference between the disinvestment cap on the firm as imposed by the Department of Disinvestment and the actual disinvestment till the previous year. We use random effects with probit model along with importance weights. The main results from this analysis may be summarized in Table 5.

Most of the results are in line with the previous analysis except one particular observation. In general, with a coalition in power which is left winged, probability of disinvestment occurrence is lower as compared to a right winged coalition. Also, if the ideological difference between the Lok Sabha government and the state government is higher, it reduces the probability of occurrence of disinvestment because disinvestment policy is a structural phenomenon. However, we find a puzzling result that high ideological spread increases the probability of disinvestment occurrence. This seems to be counter intuitive under the first impression because ideological spread has a negative impact on the first time selection of firms for disinvestment. However, one possible explanation may be as follows. Coalition governments with very high ideological dispersion (due to a mix of ideologically opposite parties) are more welcoming to divest the same public enterprise multiple times rather than divest new firms for disinvestment each time. With a disinvestment mandate to meet and realize their targeted proceeds, a coalition with ideologically dissimilar parties would prefer selecting the same firm again rather than selecting 
The table presents marginal effects for factors affecting occurrence of disinvestment of central public sector enterprises.

\begin{tabular}{|c|c|c|c|}
\hline Disinvestment Occurrence & Model I & Model II & Model III \\
\hline Ideology score & $\begin{array}{l}-41.998 * * * \\
(1.939)\end{array}$ & $\begin{array}{l}-41.308 * * * \\
(2.117)\end{array}$ & $\begin{array}{l}-41.311 \text { *** } \\
(2.117)\end{array}$ \\
\hline Ideology difference & $\begin{array}{l}-0.078 * * * \\
(0.014)\end{array}$ & $\begin{array}{l}-0.118 * * * \\
(0.015)\end{array}$ & $\begin{array}{l}-0.119 * * * \\
(0.015)\end{array}$ \\
\hline Ideology spread & $\begin{array}{l}2.117 * * * \\
(0.136)\end{array}$ & $\begin{array}{l}2.457 * * * \\
(0.160)\end{array}$ & $\begin{array}{l}2.458 * * * \\
(0.160)\end{array}$ \\
\hline Fiscal deficit & $\begin{array}{l}3.774 * * * \\
(0.434)\end{array}$ & $\begin{array}{l}3.248 * * * \\
(0.457)\end{array}$ & $\begin{array}{l}3.244 * * * \\
(0.457)\end{array}$ \\
\hline Firm age & $\begin{array}{l}0.009 * * * \\
(0.001)\end{array}$ & $\begin{array}{l}0.010 * * * \\
(0.001)\end{array}$ & $\begin{array}{l}0.010 * * * \\
(0.001)\end{array}$ \\
\hline Firm size & $\begin{array}{l}9.546 * * * \\
(1.071)\end{array}$ & $\begin{array}{l}9.890 * * * \\
(1.094)\end{array}$ & $\begin{array}{l}9.861 * * * \\
(1.094)\end{array}$ \\
\hline Firm profit & $\begin{array}{l}2.710^{* * *} \\
(0.143)\end{array}$ & $\begin{array}{l}2.774 * * * \\
(0.149)\end{array}$ & $\begin{array}{l}2.756^{* * * *} \\
(0.150)\end{array}$ \\
\hline Labor productivity & $\begin{array}{l}0.001 * * * \\
(0.000)\end{array}$ & $\begin{array}{l}0.001 * * * \\
(0.000)\end{array}$ & $\begin{array}{l}0.001 * * * \\
(0.000)\end{array}$ \\
\hline Firm efficiency & - & - & $\begin{array}{l}-0.005 \\
(0.005)\end{array}$ \\
\hline Delicensing & $\begin{array}{l}0.805 * * * \\
(0.074)\end{array}$ & $\begin{array}{l}0.943 * * * \\
(0.08)\end{array}$ & $\begin{array}{l}0.943 * * * \\
(0.081)\end{array}$ \\
\hline Geographical factors & & Yes & Yes \\
\hline Industry Dummies & & Yes & Yes \\
\hline Ratna Status & & Yes & Yes \\
\hline Squared firm Variables & & No & Yes \\
\hline No. of obs & 4615 & 4615 & 4615 \\
\hline Pseudo R squared & $27 \%$ & $30 \%$ & $30 \%$ \\
\hline
\end{tabular}

Note: The table presents marginal effects from the random effects regression analysis for occurrence of disinvestment. Standard errors are reported within parentheses. $* * *$ and $* * *$ indicate significance at $10 \%, 5 \%$ and $1 \%$ respectively. Only choice variables are reported in the table. Model I and II does not include firm efficiency. Model III includes firm efficiency. Model III includes squared terms of firm specific variables.

Table 5: Disinvestment occurrence regression using random effects probit model 
a fully owned public firm for the first time. It seems to be comparatively an easier approach. Finally, results also suggest that more experienced firms are more probable to be selected for disinvestment multiple times as compared to the newer ones. Also, firm profitability and firm size influences occurrence of disinvestment positively.

We have used all control specific variables described in the previous section. The specificity and the sensitivity numbers are $72 \%$ and $82 \%$ respectively. Also, to check for the consistency of qualitative signs and significance of each of the choice variables on our dependent variables we perform the same specifications and robustness tests that we employ in Section 9.1. Most of the results go through.

\subsection{Extent of Disinvestment}

As a final step to our study, we focus on the factors influencing the extent of disinvestment. We capture the extent of disinvestment as the share of ownership transferred from the government to the private sector. It is expressed as a real number between 0 and 1 . To study the factors that affect extent of disinvestment we examine firms that have been divested. However, of equal importance is the set of firms that have never been divested. If we focus only on firms that have been divested we have a non-random (selected) sample. To do away with this sample selection problem, we employ Heckman sample selection procedure for panel data models ${ }^{19}$. The results obtained from the second stage are presented in Table 6.

Ideology, more or less has expected impact on the extent of disinvestment. The more right winged a coalition government is, higher is the extent of disinvestment of all public sector enterprises, as opposed to a left winged coalition government in power. Ideology spread also behaves as expected. Higher ideology dispersion within a coalition has an adverse effect on the extent of disinvestment. Both ideology score and spread have a negative coefficient at 5\% level of significance. However, the coefficient of ideology difference between the Lok Sabha government and the government ruling the state is insignificant. Intuitively, most of the opposition from ideological dissimilar parties arise for selecting firms for disinvestment. Not once have these parties opposed on the extent of disinvestment.

It is observed that low profitability, productivity and low firm size tend to increase the extent of disinvestment. These variables are significant at least at 5\%. High deficit/debt positions lead to higher disinvestment. To check for the robustness of the estimates we do the following. We perform the usual diagnostic checks on the residual series for heteroskedasticity and autocorrelation. It goes through. We try various model specifications at both the stages. In the second stage we also try

\footnotetext{
${ }^{19}$ Sample Selection for panel data models has been discussed in details in Appendix D
} 
The table presents regression results from the second stage of sample selection. It presents the factors affecting extent of disinvestment of central public sector enterprises.

\begin{tabular}{|c|c|c|c|}
\hline Extent of disinvestment & Model I & Model II & Model III \\
\hline Ideology score & $\begin{array}{l}-0.462^{* * *} \\
(0.106)\end{array}$ & $\begin{array}{l}-0.326 * * * \\
(0.094)\end{array}$ & $\begin{array}{l}-0.149 * * * \\
(0.075)\end{array}$ \\
\hline Ideology difference & $\begin{array}{l}-0.017 \\
(0.012)\end{array}$ & $\begin{array}{l}-0.02 \\
(0.013)\end{array}$ & $\begin{array}{l}-0.003 \\
(0.015)\end{array}$ \\
\hline Ideology spread & $\begin{array}{l}-0.374 * * * \\
(0.105)\end{array}$ & $\begin{array}{l}-0.161 * * * \\
(0.078)\end{array}$ & $\begin{array}{l}-0.044 * * * \\
(0.022)\end{array}$ \\
\hline Fiscal deficit & $\begin{array}{l}0.002 \\
(0.349)\end{array}$ & $\begin{array}{l}1.934 * * * \\
(0.427)\end{array}$ & $\begin{array}{l}0.000 * * * \\
(0.000)\end{array}$ \\
\hline Firm age & $\begin{array}{l}0.322 * * \\
(0.068)\end{array}$ & $\begin{array}{l}0.276 * * \\
(0.067)\end{array}$ & $\begin{array}{l}0.190 * * \\
(0.052)\end{array}$ \\
\hline Firm size & $\begin{array}{l}-0.087 * * \\
(0.034)\end{array}$ & $\begin{array}{l}-0.064^{* * *} \\
(0.032)\end{array}$ & $\begin{array}{l}-0.074 * * \\
(0.034)\end{array}$ \\
\hline Firm profit & $\begin{array}{l}-0.404 * * \\
(0.176)\end{array}$ & $\begin{array}{l}-0.437 * * \\
(0.192)\end{array}$ & $\begin{array}{l}-0.409^{* *} \\
(0.195)\end{array}$ \\
\hline Labor productivity & $\begin{array}{l}0.001 \\
(0.000)\end{array}$ & - & - \\
\hline Firm efficiency & - & - & $\begin{array}{l}-0.005 \\
(0.005)\end{array}$ \\
\hline Delicensing & $\begin{array}{l}-0.274 * * * \\
(0.093)\end{array}$ & $\begin{array}{l}-0.269 * * * \\
(0.099)\end{array}$ & $\begin{array}{l}-0.207 * * * \\
(0.106)\end{array}$ \\
\hline Disinvestment scope & $\begin{array}{l}0.546^{* * *} \\
(0.108)\end{array}$ & $\begin{array}{l}0.559 * * * \\
(0.14)\end{array}$ & $\begin{array}{l}0.420 * * * \\
(0.117)\end{array}$ \\
\hline Time Dummies & & Yes & \\
\hline No. of Obs & 158 & 158 & 158 \\
\hline R- square & $4 \%$ & $4 \%$ & $5 \%$ \\
\hline
\end{tabular}

Note: The table presents results obtained from the second stage regression analysis for factors affecting the extent of disinvestment. Standard errors are reported within parentheses. *** and $* * *$ indicate significance at $10 \%, 5 \%$ and $1 \%$ respectively. Only choice variables are reported in the table. Model I and II does not include firm efficiency. Model II includes firm efficiency. Model III includes squared terms of firm specific variables.

Table 6: Extent of disinvestment regression using sample selection- second stage results model 
poisson specification since disinvestment is a rare occurrence. The variables behave consistently. Also, as mentioned before we remove the "outlier" first year of disinvestment implementation to check the robustness, and repeat the entire exercise. We get similar results.

\section{Conclusion}

Using a comprehensive dataset of all enterprises owned by the Central government of India for the period of 1991-92 to 2010-11, the paper aims to explore the factors affecting the a) selection of firms for disinvestment, b) occurrence of disinvestment and c) the extent of disinvestment of such firms. Using panel data estimation for limited dependent variable and sample selection models, we specifically explore the role of ideology in disinvestment decisions.

Since we are particularly interested in elucidating the role of ideology in disinvestment decisions made by the central government, we construct three measures for that purpose: i) ideology score of a coalition, ii) ideology spread of a coalition and iii) ideology difference between centre and the state in which the public sector enterprise is located. We hypothesize that disinvestment is falling in the ideology score. The empirical investigation confirms the importance of ideology score in disinvestment decisions.

The intuition behind using ideology difference is as follows. Since disinvestment is mostly irreversible and structural in nature, it may be difficult for the Central government to adopt disinvestment in states where the ideologically dissimilar parties have won the state-level elections. So, we expect higher ideological difference between the Central government and the state-level government to have a detrimental impact on disinvestment. This is reflected in our results. It is seen that both the selection of firms for disinvestment and occurrence of disinvestment becomes more probable with low ideological difference. However, it is insignificant in explaining the extent of disinvestment as expected.

The third measure of ideology is the ideological spread in a coalition government. It is the weighted variance of the coalition government. Any coalition government with a high ideological spread will face difficulties in implementing a "politically unpopular policy" as disinvestment. We find that ideological spread has a negative coefficient (significant at $1 \%$ ) in explaining first time selection of firms for disinvestment but a positive coefficient (significant at 1\%) for disinvestment occurrence. This suggests that for coalitions with high ideological dispersion, while trying to meet their disinvestment targets it is less costly to divest the same firms rather than choose new ones. 
While (Dinc and Gupta (2011)) deal with political economy of disinvestment in India, our study is different from theirs in several dimensions. First of all, Dinc and Gupta (2011) focus on the effect of electoral competition on the decision of privatization. This study, on the other hand, has a broader objective. First, it focuses on the role of ideology in a coalition deciding to disinvest. Secondly, by investigating into different aspects of the disinvestment decision, the present study also suggests a specific pattern followed by the government. Further, Dinc and Gupta (2011) investigate only the first time selection of firms for disinvestment where as the present study explores three specific features of disinvestment.

However, there may be comparison of the two studies on the role of centre state factors affecting disinvestment decisions. Dinc and Gupta (2011) emphasize on how high electoral competition would reduce the probability of disinvestment of a firm situated in the state. ${ }^{20}$ This study suggests how ideology difference between the centre and state affects disinvestment inversely. To show that the two measures are unrelated to each other let us consider the following scenario. Suppose there are two states 1 and 2. Assume that the ideology difference with respect to the centre in the two states are 0.1 and 5 respectively. Further, let the seat share difference in the two states for the central government running party and it's opposition be 0.1 and 0.6 respectively. According to the current approach, probability of disinvestment is higher in 1 than in 2 because the centre is more ideologically similar to state 1 as compared to 2. However, Dinc and Gupta (2011) electoral competition measure would suggest that the centre would select a firm from state 2 as compared to state 1 because state 1 is characterized with strong opposition. This shows that there is no one-to-one correspondence between ideology difference and electoral competition and so the measures used in both the studies are completely unrelated.

Further, the results suggest that the government seems to make a dual move in selection of firms and deciding the extent or magnitude of disinvestment. With the back drop of inefficiencies associated with CPSEs back in 1980s and the disinvestment policy targeting at improving the performance of CPSEs one would expect poor performing CPSEs to be eligible candidates for disinvestment. However, the twin objective of minimizing deficit and debt would call for the government to pick the most productive firms (we get positive significant coefficients for deficit in our analysis). The results from our regression analysis suggests that the government selects relatively profitable and bigger CPSEs for disinvestment. Surprisingly, the extent of disinvestment is higher if the CPSEs is smaller in size, newer and less

\footnotetext{
${ }^{20}$ Dinc and Gupta (2011) define electoral competition as "To measure the extent of political competition between the governing and the opposition party alliances, we define Vote Share Difference as the difference between Government Vote Share and Opposition Vote Share, which assumes a lower value in constituencies where the governing and opposition parties are in a close race, or where the opposition party alliance is stronger"
} 
profitable. Therefore, the government selects the best CPSEs to get high proceeds from disinvestment and from that set, it divests the relatively poor firms more than the better ones.

\section{Appendix A}

The description and construction of each of the variables used in the analysis has been discussed in details.

\section{Firm Specific variables}

We use an array of firm specific variables which may be broadly classified into firm profile specific variables and firm performance variables. Among firm profile specific variables we consider firm age and firm size. Firm age is the number of years that a firm has been operating since inception. It captures the experience of a firm. Firm size has been identified as one of the most important control factors when considering firm performance both in the empirical and theoretical literature. We have also considered firm performance variables - including firm profit, productivity and efficiency. These are simple firm accountancy measures but a mix of these measures gives the overall firm performance scenario. Firm profitability is measured $b$ the ratio of profit after tax to total assets. For firm productivity, we use both average product of capital and average product of labour. For efficiency we use operating efficiency. Each of these variables is notationally represented as follows:

$$
\begin{gathered}
\text { Age }_{i j}=\left[\text { Currentyear }^{\text {Yearofincorporation }]}\right. \\
\text { Size }_{i j}=\log \left[\text { Totalasset }_{i j}\right] \\
\text { Profitability }_{i j}=\frac{\text { PAT }_{i j}}{\text { Totalasset }_{i j}} \\
\text { APLabor }_{i j}=\frac{\text { Totalsales }_{i j}}{\text { Employeestrengt }_{i j}} \\
\text { APCapital }_{i j}=\frac{\text { Totalsales }_{i j}}{\text { Capitalemployed }_{i j}}
\end{gathered}
$$


All the variables have standard notations where $i$ denotes the firm and $j$ denotes the year. The expected relation between these firm specific variables, as discussed while laying out the hypotheses, may be positive or negative with disinvestment decisions. The actual relationship between the two for the Indian context will be explored further with the help of econometric tools.

\section{Control factors}

We use a series of control factors. We start with the political factors.

\subsubsection{Political factors}

Political fragmentation using Effective Number of Parties: This captures how fragmented the government in power is. It brings out the difference between a coalition and a single party government by quantifying the fragmented structure of the government. It was originally designed by Laakso and Taagpera (1979). It is a measure of the level of concentration in political life which assigns more influence to large parties and screens out very small parties in its computation. It can be simply defined as the inverse of the sum of the squared proportion of seats won by each electoral party.

$$
E N P_{i j}=\frac{1}{\sum_{i=1}^{N} w_{i j}^{2}}
$$

where $w_{i j}$ is the proportion of seats won by $i$ th party in the $j$ th year. The number of parties equals the effective number of parties only when all parties have equal strength. In any other case, the effective number of parties is lower than the actual number of parties. The effective number of parties is a frequent operationalization for the fragmentation of a party system. This measure has been widely used in the empirical literature involving studies investing the determinants of partial privatization (known as disinvestment in India). A few of the studies are Bortolotti and Pinotti (2008), Haggard and Kaufman (1997) and Mainwaring and Shugart (1997). The empirical literature has reached a consensus in identifying a negative relationship between political fragmentation and disinvestment decision.

Stability of Centre Government: Frequent changes in government make implementation of reforms more difficult and increase the likelihood of policy reversals. Furthermore, when constantly under threat of losing office, governments may not be willing to introduce politically costly measures, such as disinvestment, which 
requires gradual implementation. So stability of he government is a critical requirement for successful implementation of a not-so-well accepted policy like disinvestment. In fact, we have used a two- dimensional stability concept. More specifically we use two measures of stability. The first captures the instability in terms of number of seats won by the coalition and the deviation of this from the magical number 272. The second measure captures the number of days the government has been in power. These two measures deal with two different aspects of stability. The first is an exante measure of stability where as the other is expost.

Stability in days: During the period of the analysis, the political conditions in India, pertaining to the Lok Sabha has a very interesting mix of highly unstable and stable governments. On one hand, India has faced unstable political conditions during the eleventh and twelfth Lok Sabha terms, whereas on the other hands the 13th and 14th Lok Sabha terms had been stable. Against this backdrop, it would be interesting to include this variable in our analysis. We measure the stability of a government as the duration of Lok Sabha during which the political party (parties) was in power. In other words, it is measured by the ratio of the number of days between the date of commencement and dissolution of the ruling party during the corresponding Lok Sabha term to the maximum number of days possible (365*5 days). Clarke and Cull (2002) have measured the stability as the number of years in term. Information on this variable is retrieved from the Lok Sabha website. It is represented as

$$
\text { Stabilityindays }_{j}=\frac{\text { Daysinpower }_{j}}{365 * 5}
$$

Exante Stability Elections to the Lok Sabha, the lower house of the federal parliament, are held under majoritarian winner-takes-all electoral rules, with members elected from 543 single member constituencies. A simple majority of 272 seats is needed to form a government. In the past, the electoral rules gave the bigger parties seat bonuses in parliament, but with the rise of regional parties - often stronger in India's component states than national parties - the bonus contracted. Exante stability is a score that measures how stable the coalition is with respect to the magical number of seats (272). It is constructed on the simple assumption that a government with seats less than 272 is perceived to be unstable by the public. In fact, the further the number of seats won by the coalition the higher is the perceived instability for it. The measure captures another important aspect of instability. In a coalition, besides the stability of the over all coalition what is equally important is how stable the majority party (leader) is in the coalition. We construct a measure 
that assigns importance to both the stability of the coalition and the stability of the main party in the coalition. It is formulated as follows.

$$
\text { Stabilityseats }_{j}=\frac{1}{\left[\frac{a_{j}-272}{a_{j}}+\frac{b_{j}-272}{b_{j}}\right]}
$$

where $a_{j}$ and $b_{j}$ are the number of seats won by the main party and the coalition in the $j$ th year respectively. In the denominator, the first term captures the extent of instability due to the coalition and the second term captures the extent of instability due to the main party. By summing it we get the instability of the main party and the coalition. The inverse of this term gives a measure of stability of the government. Both stability measures should have a direct and positive effect on disinvestment decisions.

\subsubsection{Macroeconomic Factors}

Macroeconomic factors have been identified as important determinants of disinvestment decision in the empirical literature investigating the causes of disinvestment. The government of India had also mentioned that one of the key objectives of disinvestment was to bridge the deficit/ debt gap. Severe crisis situation, poor macroeconomic conditions open gates to structural and irreversible policy options as disinvestment. We have used stock market returns, average real per capita income, average real per capita fiscal deficit and average real per capita total debt taken by the govt. All variables except the stock market returns is converted into natural logarithm. Average real per capita income and average real per capita fiscal deficit have bee used at a 5 year lagged average values to incorporate the fact that disinvestment is a structural process and it would be either an abnormal slump in the GDP of a country or longer periods of deficit and debt positions which would force authorities to resort to such measures. We collect the data on GDP, deficit and debt from the Reserve Bank of India website. To adjust for inflation, all these variables are converted into real values by the IIP (base year 2004-2005). For GDP, we have real per capita gross domestic product at constant price (with base year as 2004-05). We use annual gross fiscal deficit of India. It is defined as the excess of total expenditures (including loans net of recovery) over revenue receipts (including external grants) and non-debt capital receipts. It gives the signal to the government about the total borrowing requirements from all other sources. To adjust for inflation we use IIP values (base year 2004-05). We also use the total debt of the Centre that has accumulated over the years and consists of both external and internal debt. Since it is an accumulated variable we take one period lagged value. 
Accoring to Bortolotti et al. (2004) an important element of financial development is stock market. We take the stock market performance to capture prevailing market conditions. The data has been extracted from the NSE website. After extracting the historical daily price data for S\&P CNX Nifty from 3rd July 1990 to 2010, we take the closing price of the first and the last trading day in the financial year (April to March). We calculate the return using these two values for the entire annual year. So, the annual return will be the last day closing price minus the first day closing price divided by the closing price of the first day.

$$
R_{j}=\frac{P_{j}-P_{j-1}}{P_{j-1}}
$$

where $P_{j}$ is the closing price on the last trading day in the $j$ th year and $R_{j}$ is the annual return in the $j$ th year.

\subsubsection{Industry specific factors}

Finally, disinvestment decisions are dependent on the prevailing competition in a particular industry. One of the objectives for inception of disinvestment was to infuse competition into industries which are not competitive enough. In this respect, it may be reasonable to expect that firms operating in industries, which are selected for delicensing (an indicator of rising competition), will be averse to disinvestment. To capture the competitiveness in a particular industry and to check the overall changing competitiveness in an industry we construct a variable- delicensing. For every 2 digit NIC industry, we calculate the proportion of 4 digit NIC industries that were delicensed in a particular year. For the manufacturing sector, we get a time series of the 'delicensing' variable. For the services sector, we collect information from govt websites and documents for similar reforms and add it to the variable. This gives us our "delicensing" variable.

\section{Policy Changes}

Also, to control for changes in disinvestment policy over time we construct another important variable, named disinvestment scope. It is the scope of disinvestment for a particular firm. It is the difference between disinvestment cap and total disinvested percentage in that firm till the last year. This variable captures the scope of further disinvestment in firms. Disinvestment cap is calculated by the maximum disinvestment allowed in a particular industry. This information is collected from the ministry of disinvestment policy documents and announcements. Besides these 
important controls we include dummies to control for industries, overtime effect, geographical location and ratna status of each public sector enterprise.

\section{Appendix B}

The summary statistics of all the important variables are presented in Table 7:

\section{Appendix C}

Panel data with dichotomous dependent variable requires more sophisticated methods than panel data with continuous dependent variable or cross section data with dichotomous dependent variable. While dealing with static cross section data the choice between employing logit or probit framework depends on the distributional assumptions made for the disturbance term. Also, with continuous dependent variable in panel data the individual specific effects are assumed to be fixed or random. However, when trying to combine the two models where a dichotomous dependent variable is estimated in a panel data structure the use of logit or probit basically will depend on the choice between fixed or random effects. If the time period of analysis $(T)$ is very small compared to the number of cross sectional units $(N)$, a fixed effects model leads to inconsistent estimates. Use of fixed effects model with probit leads to incidental parameters problem in which the estimation of the dependent variables is conditional not just on the exogenous variables but also on these fixed effects variables. So these fixed effects variables are treated as parameters to be estimated. In this respect, with fixed $T$ and $N$ estimation becomes inconsistent. So with probit model comes the assumption of random effects. Logit specification with random effects is less desirable because estimation is complicated as the response probability obtained does not have a closed form. The use of logit model with fixed effects is restricted by those observations whose outcome changes. Given this, we employ the random effects with probit model for our estimation. The model can thus be presented by the following econometric set up:

$$
Y_{i t}=\alpha_{i}+\beta X_{1 i t}+\gamma X_{2 i t}+\delta X_{3 i t}+\mu X_{4 i t}+\varepsilon_{i t}
$$

for all $i=1,2 \ldots, N$ and $t=1,2, \ldots, T$

where $Y_{i t}$ indicates if the $i$ th firm has been selected for disinvestment in the $t$ th year or not; $\alpha_{i}$ indicates the firm specific unobserved variables and $\varepsilon_{i t}$ is the error term; $X_{1 i t}, X_{2 i t}, X_{3 i t}$ and $X_{4 i t}$ are vectors representing the firm specific factors, industry specific, macroeconomic and political factors affecting the decision 
The table presents summary statistics for important variables

\begin{tabular}{|c|c|c|c|c|}
\hline Variable & Mean & Std. Dev. & Min & Max \\
\hline Extent of delicensing & 0.86 & 0.272 & 0 & 1 \\
\hline Scope for disinvestment & 0.413 & 0.352 & -0.1 & 1 \\
\hline Ideological Difference & 0.307 & 1.486 & -2.08 & 3.583 \\
\hline Ideological Score & 2.507 & 0.681 & 1.417 & 3.08 \\
\hline Ideological spread & 0.738 & 0.799 & 0 & 2.949 \\
\hline Effective number of parties & 5.24 & 1.029 & 3.7 & 6.5 \\
\hline No. of parties & 13.464 & 8.281 & 1 & 23 \\
\hline Repition Dummy & 0.302 & 0.459 & 0 & 1 \\
\hline Year of Term & 2.515 & 1.379 & 1 & 5 \\
\hline Stock Return & 0.261 & 0.578 & -0.482 & 2.385 \\
\hline Per capita income & 10.161 & 0.136 & 9.939 & 10.417 \\
\hline Per capital Fiscal Deficit & 7.202 & 0.128 & 7.017 & 7.425 \\
\hline Per capita Total Debt & 9.544 & 0.282 & 8.988 & 9.882 \\
\hline Firm age (lagged value) & 26.498 & 17.402 & 0 & 212 \\
\hline Return on Assets (lagged value) & -0.043 & 1.302 & -40.096 & 32.015 \\
\hline Return on Sales (lagged value) & 0.736 & 32.934 & -171.141 & 1980 \\
\hline Labor size (lagged value) & 3.064 & 0.998 & -1 & 6.215 \\
\hline Firm size (lagged) & 21.629 & 2.405 & 13.122 & 27.9 \\
\hline Return on capital (lagged value) & 0.195 & 7.434 & -176.778 & 229.075 \\
\hline Expost Stability & 0.744 & 0.284 & 0.219 & 0.986 \\
\hline Exante Stability & 1.838 & 2.048 & -1.162 & 4.357 \\
\hline Asset weight & 0.004 & 0.012 & 0 & 0.091 \\
\hline
\end{tabular}

Source: Master dataset

Table 7: Summary statistics of variables 
of disinvestment. We use conditional MLE to get the signs and significance of the relevant coefficients.

\section{Appendix D}

According to Wooldridge (2001), sample selection can only be an issue once the population of interest has been carefully specified. If we are interested in a subset of the population, then the proper approach is to specify a model for that part of the population, obtain a random sample from that population and proceed with standard econometric methods. In this respect, we employ a Heckman selection model, which helps in delivering consistent estimates. The Heckman model requires two dependent variables in order to capture both the selection and outcome stage. The selection stage begins with the decision to go for disinvestment or not and the outcome stage deals with size and extent of disinvestment. This model allows one to control for selection bias, thus avoiding misinterpretation of the substantive causal effects of particular variables due to correlation between exogenous variables and the disturbance term. This estimation procedure models a process that begins with selection (disinvestment or not), followed by a decision over a continuous outcome (size and extent of disinvestment).

Bortolotti et al. (2004) also discuss about the sample selection problem that they have ignored in their analysis and caution their readers about it. However, Sprenger (2006) uses a similar methodology. He argues "In addition, observations with zero ownership stake are often due to the fact that these firms were not disinvested by the date under consideration, July 1, 1994. If we would analyze only disinvested firms, our sample would not be random any more and the results would be biased. A model structure that integrates both stages, the privatization decision and the extent of ownership by a particular type of owner within its natural limits, is a model with selection. We also employ the same approach and follow Wooldridge (2001) .

The first step is to test for sample selection in our model. We add the lagged selection indicator, $s_{i, t-1}$ to the equation, estimate the model by fixed effects (on the unbalanced panel) and do a t test for the significance of $s_{i, t-1}$. Under the null hypothesis, uit is uncorrelated with sir for all $\mathrm{r}$, and so selection in the previous time period should not be significant in the equation at time t. However, if this estimate is significant, we employ sample selection technique for panel data.

After testing for the presence of selection bias we find that our sample is a selected sample and hence we employ sample selection panel data estimation methods. We estimate a pooled probit selection model using clustering option and relevant time dummies. This is the first stage which yields the inverse mills ratio. 
We also use an exclusion restriction which is the initiation of disinvestment programme. The number of years since initiation affects the selection of firms but does not affect the extent of disinvestment as the latter is driven more by the targeted receipts to be met. In the second stage, we estimate the outcome equation on the selected sample by fixed effects using inverse mills ratio as an additional explanatory variable. The exclusion restriction is not included in this step.

The estimation method employs two stages. In the first stage we consider all firms (whether divested/ not divested) and run a pooled probit model to capture the decision of disinvestment. We use importance weighting scheme and weigh all the observations by the average natural logarithm of assets over all the years. We also use robust and clustered standard errors by clustering at the political variable level to obtain unbiased and efficient estimates. The dependent variable typically takes the value 1 when selected for disinvestment in a particular year and 0 otherwise. This is called the decision stage. To control for the sample selection we need to include one/few instrument variables (IV). This set of variables takes care of the exclusion restriction criterion which requires the IV to be correlated only with the decision of disinvestment but not with the extent of disinvestment. The instrumental variable used in this analysis is the distance from crisis, measured as the number of years from the inception of disinvestment policy (1991-92). We estimate this pooled model controlling for time, industry, geographical and ratna status of public sector enterprises. We also employ the usual political and macroeconomic control variables. Changes in competition levels in various industries are captured using a variable 'de-licensing'. We obtain the inverse mills ratio from the decision equation by using the predicted values. The instrumental variable is significant at $1 \%$ with a negative coefficient. This implies that as the distance from 1991 crisis increases, probability of disinvestment occurrence drops.

We then come to the second stage of our estimation, called the outcome stage. In this stage we estimate a fixed effects model for only those observations for which selection of disinvestment, dependent variable in the decision stage, takes the value 1 . Also, to infuse randomness in the outcome stage we take inverse mills ratio and do not use the distance from crisis variable. The economic rationale behind this is fairly simple. As the distance from crisis increase, it affects the selection of firms for disinvestment. The extent of disinvestment is rather unaffected by the extent. Extent may be driven by other objectives, reviving enterprises or/and bridging the deficit gap. 


\section{References}

Biais, B. and E. Perotti (2002): "Machiavellian privatization," American Economic Review, 92, 240-258.

Biglaiser, G. and D. S. Brown (2003): "The determinants of privatization in latin america," Political Research Quarterly, 56, 77-89.

Bjornskov, C. (2005): "Does political ideology affect economic growth?" Public Choice, 123, 133-46.

Bjornskov, C. (2008): "The growth inequality association: Government ideology matters," Journal of Development Economics, 87, 300-8.

Bjornskov, C. and N. Potrafke (2011): "Politics and privatization in central and eastern europe: A panel data analysis," Economics of Transition, 19.

Boehmer, E., R. C. Nash, and J. M. Netter (2005): "Bank privatization in developing and developed countries cross-sectional evidence on the impact of economic and political factors," Journal of Banking and Finance, 29, 1981-2013.

Bortolotti, B., M. Fantini, and D. Siniscalco (2004): "Privatisation around the world: evidence from panel data," Journal of Public Economics, 88, 305 - 332.

Bortolotti, B. and P. Pinotti (2008): "Delayed privatization," Public Choice, 136, 331-351.

Bortolotti, B. and D. Siniscalco (2004): The Challenges of Privatization: An International Analysis, Oxford scholarship online.

Boubakri, N., J.-C. Cosset, O. Guedhami, and W. Saffar (2011): "The political economy of residual state ownership in privatized firms: Evidence from emerging markets," Journal of Corporate Finance, 17, 244 - 258.

Chhibber, P. and I. Nooruddin (2004): "Do party systems count?: The number of parties and government performance in the indian states," Comparative Political Studies, 37, 152-187.

Clarke, G. R. G. and R. Cull (2002): "Political and economic determinants of the likelihood of privatizing argentine public banks," Journal of Law and Economics, 45, 165-97.

Dash, B. B. and A. V. Raja (2014): "Do political determinants affect revenue collections? a study of the indian states," International Review of Economics, 3, 253-278.

Dinc, I. S. and N. Gupta (2011): “The decision to privatize: Finance and politics," The Journal of Finance, 66, 241-269.

Erikson, R. S. and K. L. Tedin (2003): American Public Opinion: Its Origin, Contents, and Impact, New York: Longman.

Haggard, S. and R. R. Kaufman (1997): "The political economy of democratic transitions," Comparative Politics, 29, 263-283. 
Heckman, J. J. (1979): "Sample selection bias as a specification error," Econometrica, 47, 153-61.

Jost, J. T., C. M. Federico, and J. L. Napier (2009): "Political ideoology: Its structure, functions and elective affinities," Annual Review of Psychology, 60, 307-37.

Laakso, M. and R. Taagpera (1979): "Effective number of parties: A measure with application to west europe," Comparative Political Studies, 12, 3-27.

Mainwaring, S. and M. Shugart (1997): Presidentialism and Democracy in Latin America, Cambridge Studies in Comparative Politics.

Megginson, W. L., R. C. Nash, J. M. Netter, and A. B. Poulsen (2004): "The choice of private versus public capital markets: Evidence from privatizations," Journal of Finance, 59, 2835-2870.

Megginson, W. L. and J. M. Netter (2001): "From state to market: A survey of empirical studies on privatization," Journal of Economic Literature, 39.

Mizutani, F. and S. Uranishi (2010): "Determinants of privatization of public corporations: evidence from the japanese experience," Empirical Economics, 39, $515-535$.

Naib, S. (2004): Disinvestment in India: Policies, Procedures, Practices, Sage Publications.

Perotti, E. C. (1995): “Credible privatization,” The American Economic Review, 85, pp. 847-859.

Potrafke, N. (2010): "Does government ideology influence deregulation of product markets? empirical evidence from oecd countries," Public Choice, 143.

Sprenger, C. (2006): "The determinants of ownership after privatisation the case of russia," Working Paper.

Sridharan, E. (2010): The fragmentation of Indian Party System, 1952- 2009: Seven Competing Explanations.

Wooldridge, J. (2001): Econometric Analysis of Cross Section and Panel Data, MIT Press. 
The panel of graphs show the trend followed by the disinvestment proceeds and number of firms selected for disinvestment in figures 1(a) and 1(b) respectively against the political background. The pink background colour denotes INC dominated government and blue colour denotes BJP dominated government.

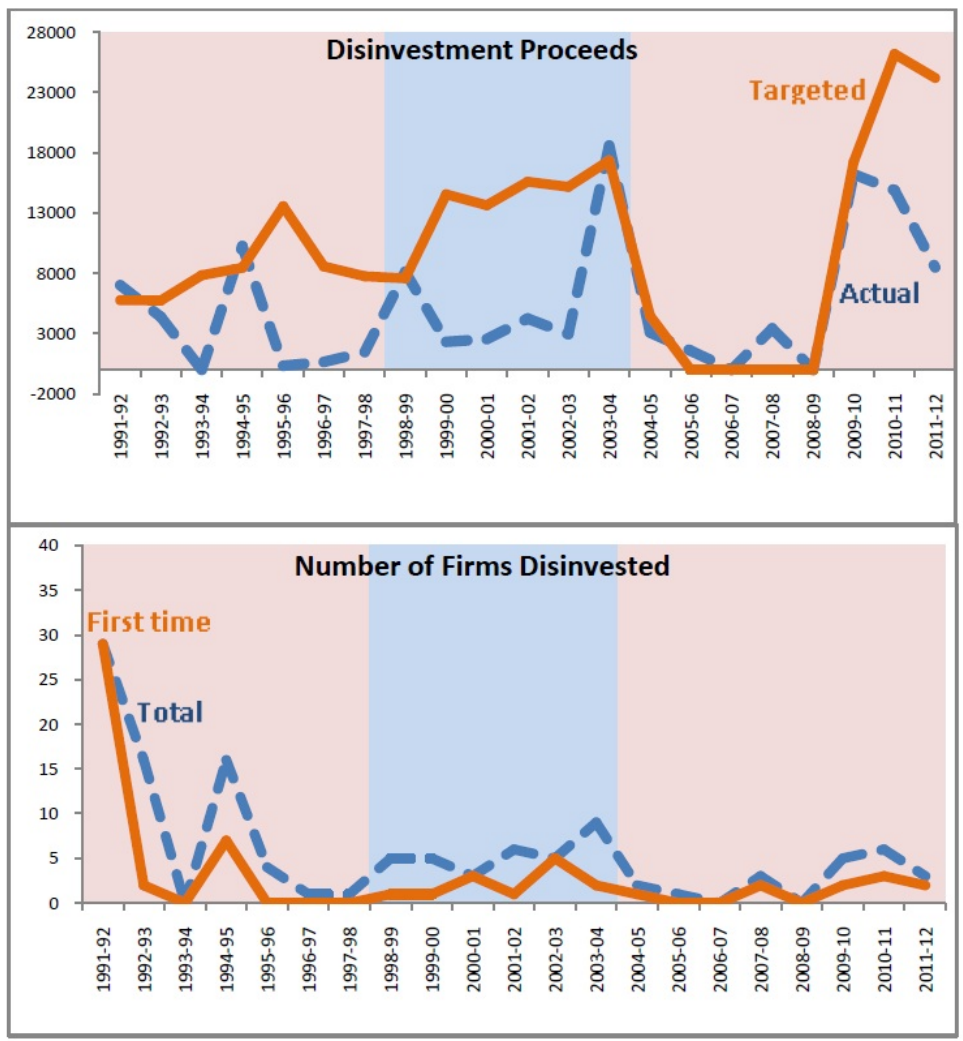

Figure 1: Disinvestment trends against the political background between 1991-92 and 2011-12 